\title{
Contributions of ENDOBACT multicentric study to the infective endocarditis etiology in Romania
}

\section{Contribuții ale studiului multicentric ENDOBACT la precizarea etiologiei endocarditei infecțioase în Romania}

\author{
Mihaela Oprea $^{1 *}$, Maria Surdeanu ${ }^{1}$, Daniela Badescu ${ }^{2}$, Ani Ioana Cotar ${ }^{2}$, \\ Sorin Dinu ${ }^{1}$, Otilia Banu ${ }^{3}$, Mirela Flonta ${ }^{4}$, Monica Straut ${ }^{1}$ \\ 1. "Cantacuzino" National Institute of Research-Development for Microbiology and Immunology, \\ Molecular Epidemiology Laboratory, Bucharest, Romania \\ 2. "Cantacuzino" National Institute of Research-Development for Microbiology and Immunology, \\ Vector-Borne Infections Laboratory, Bucharest, Romania \\ 3. "Prof. C.C. Iliescu” Emergency Institute of Cardiovascular Diseases, Microbiology Laboratory, \\ Bucharest, Romania \\ 4. Clinical Hospital for Infectious Diseases Cluj-Napoca, Microbiology Laboratory, Cluj-Napoca, Romania
}

\begin{abstract}
The multicenter ENDOBACT study aimed at implementing molecular methods for identification of bacterial species encountered in infective endocarditis, and at attempting to reduce the number of cases with unknown etiology. For eighty seven cases was established a diagnosis of definite infective endocarditis. Thirty two of these cases had negative blood cultures. For nine cases out of 32, valve pieces were available and an attempt was made to identify the etiological agent by molecular techniques. Thirty seven available isolates were identified by phenotypical and molecular comparative methods: $16 \mathrm{~S}$ rRNA (all available isolates), rpoB (staphylococci, streptococci and enterococci), sodA (streptococci and enterococci) genes sequencing. For eight isolates, the comparative results were discrepant. Species identification of one coagulase negative staphylococcal strain was assigned using molecular methods. Molecular identification methods applied here might represent an added value for clinical and conventional microbiological diagnosis of infective endocarditis in Romania.
\end{abstract}

Keywords: infective endocarditis, ENDOBACT, DNA sequencing

\section{Rezumat}

Studiul multicentric ENDOBACT a avut ca scop implementarea metodelor moleculare de identificare a speciilor bacteriene implicate in endocardita infecțioasă, precum şi încercarea de a diminua numărul cazurilor cu etiologie neprecizată. Din 87 de cazuri diagnosticate ca endocardita infecțioasă definitivă, 32 de cazuri au

"Corresponding authors: Mihaela Oprea, "Cantacuzino" National Institute for Research and Development in Microbiology and Immunology, Splaiul Independentei, No.103, 050096, Bucharest, Romania, Tel.: +40 213069 223, Fax: +40 213069 307, E-mail: moprea@ cantacuzino.ro 
prezentat hemoculturi negative. Pentru nouă din aceste cazuri, s-au prelevat fragmente de țesut valvular şi s-a incercat identificarea agentului etiologic din acestea, aplicand tehnici moleculare. Treizeci şi şapte izolate bacteriene au fost identificate simultan, prin metode fenotipice şi moleculare: secvențierea genelor ARNr 16S (pentru toate izolatele), rpoB (pentru tulpini de stafilococi, streptococi şi enterococi) şi sodA (pentru tulpini de streptococi şi enterococi). Pentru opt izolate bacteriene, rezultatele obținute prin cele două tipuri de metode nu au coincis. Identificarea unei tulpini de stafilococ coagulază negativ a putut fi completată prin aplicarea metodelor moleculare. Metodele moleculare de identificare aplicate în acest studiu, ar putea reprezenta o valoare adaugată pentru diagnosticul clinic şi microbiologic convențional al endocarditei infecțioase practicat în România.

Cuvinte cheie: endocardita infecțioasă, ENDOBACT, secvenţiere ADN

Received: 19 $9^{\text {th }}$ December 2012; Accepted: $26^{\text {th }}$ April 2013; Published: $15^{\text {th }}$ June 2013.

\section{Introduction}

Infective endocarditis (IE) is defined as an infection of the endocardial surface of the heart. It is a serious and evolving disease with a persistently high morbidity and mortality, in spite of progress regarding infectious diseases and cardiovascular pathology. The investigation and management of IE in the developed world have changed permanently since the non-invasive imaging, molecular science, diagnostic protocol and curative surgery are all available. However, the incidence remains unchanged, about 1.7 - 6.2 cases per 100000 patients-year (1-3).

Development of endocarditis is initiated by injury of the endothelium, which disrupts the normal valve structure and exposes underlying tissues. Deposition of host proteins, such as fibrin and platelets leads to the formation of a sterile thrombotic vegetation. Pathogens circulating in the bloodstream as a result of transient bacteremia bind to this coagulum and activate monocytes to produce cytokines, resulting in progressive enlargement of infected vegetation. After valve colonization, the infecting microorganisms become fully enveloped by vegetation. Under this protection, they can survive and avoid host defenses (2).

Infection of the cardiac valves or mural endocardium is caused mainly by bacteria (streptococci, staphylococci, enterococci and less commonly, rickettsiae, chlamydiae, mycoplasmas, etc.), fungi and viruses (4).

The diagnosis of IE requires a multifa- ceted approach involving clinical examination and laboratory investigation, traditionally microbiological analysis of blood cultures.

As the antimicrobial treatment is essential for therapy, a correct identification of causative bacteria is very important for choosing the appropriate antibiotic.

Conventional phenotypical identification techniques do not always lead to an accurate etiological diagnosis (5). In the genomic era, sequencing of 16 rRNA gene is a widely accepted tool for identifying bacterial isolates. The diagnostic utility of broad range 16S rRNA PCR has been already demonstrated in patients with culture-positive and culture-negative endocarditis (4, 6-10). However, the discriminative power of $16 \mathrm{~S}$ rRNA gene sequencing, especially for staphylococci, streptococci and enterococci species is limited (11-13). For differentiating such species, alternative targets can be used, namely genes with a higher variability of nucleotide sequences than $16 \mathrm{~S}$ rRNA gene. Partial sequencing of $r p o B$ (encoding-highly conserved $\beta$ subunit of the bacterial RNA polymerase) and $\operatorname{sodA}$ (encoding manganese-dependent superoxid dismutase) genes proved to be useful tools for species identification in Staphylococcus, Streptococcus, Enterococcus and other related genera $(11,14,15)$.

Blood culture negative endocarditis (BCNE) represents a well-known clinical problem occurring in large range of patients (2.5 $31 \%$ ) among IE cases $(7,8,16,17)$. Blood sampling after previous antibiotic treatment, and/or the presence of fastidious microorgan- 
isms (e.g. Gram negative bacilli belonging to HACEK group, nutritionally deficient streptococci, intracellular bacteria) are listed among the causes of blood culture negative cases. An important amount of BCNE may be due to Q fever endocarditis, determined by a chronic infection with Coxiella burnetii (16).

For surgically treated patients with BCNE, molecular analysis of resected valves proved to be very valuable when fastidious microorganisms are suspected or the patients were previously treated with antibiotics. Bacterial DNA could be extracted directly from anatomic pieces and taxonomic identification assessed by 16S rRNA gene sequencing $(7,9,17)$.

In our country, we confront with a scarcity of data regarding the major microorganisms involved in endocarditis etiology. Only few, local studies are available (18-21).

The ENDOBACT project was initiated by a group of researchers working in research-development field, public health system and academic domain. Cardiologists, infectious disease specialists, cardiac surgeons, biochemists and microbiologists created a complex partnership in order to determine the prevalent bacterial causes of IE in Romania, thus diminishing the number of cases without defined etiology.

\section{Material and methods}

\section{Patients}

ENDOBACT study was carried out from January 1, 2009 until April 15, 2011. Patients were enrolled in four major cardiovascular clinics in Romania. Written informed consent of all patients was obtained and for each patient an information sheet was completed by the physician in charge, with relevant epidemiologic, clinical, echocardiographic and biological data.

Duke's modified criteria were used to classify cases as possible or definite IE (22). When the study ended, all the cases were reanalyzed and only definite IE cases were taken into account for further studies.

\section{Laboratory procedures}

\section{Phenotypic conventional methods}

Phenotypical methods were carried out at the local laboratories of centers involved in the study.

For each patient at least three pairs of blood cultures (one set including an aerobic and an anaerobic blood culture bottle) were performed in local laboratories. Seven to ten milliliters of blood samples were inoculated in BacT/ALERT standard aerobic and anaerobic blood culture bottles (BioMerieux Inc., Durham, USA). For samples collected from patients on antibiotic treatment, charcoal containing media (FAN aerobic and anaerobic bottles) were used. Bottles were incubated in the BacT/ALERT system for 3 weeks before final negative results were reported. Pathogens from positive bottles were cultured on standard media and identified using API strips (BioMerieux Inc., Durham, USA) or Vitek2 Compact system (BioMerieux Inc., Durham, USA), according to the available infrastructure of the participating laboratories.

Heart valves excised from operated patients were transported from surgery to the local laboratory in sterile dry containers and divided into two parts under laminar flow hood. One piece of abnormal tissue was cultured on enrichment nutrient broth and incubated for a maximum of 7 days with subsequent recultivation. The remaining samples were stored at $-70-80^{\circ} \mathrm{C}$ before DNA extraction for molecular study.

The isolates and valve pieces were transported to the coordinator of this project, "Cantacuzino" NIRDMI for further molecular investigations.

\section{Molecular methods}

Available isolates identified by conventional phenotypic methods were subjected also to molecular identification. Additionally, samples of abnormal valves were prepared for bacterial DNA extraction and identification.

DNA extractions were performed using NucleoSpin Tissue commercial kit (Macheray 
Nagel, Germany) or PureLink Genomic DNA Mini kit (Invitrogen CA, USA), according to manufacturer's instructions. DNA extracted both from bacterial isolates and directly from valvular fragments was used in PCR reactions.

PCR amplifications. 16S rRNA gene: the universal eubacterial forward primer Ad and reverse primer $\mathrm{rJ}$ were used for this purpose, to amplify the 1500 bp gene (23). PCR mixtures were subjected to a denaturation step of $94^{\circ} \mathrm{C}$ for 4 min, 35 cycles of denaturation at $94^{\circ} \mathrm{C}$ for $1 \mathrm{~min}$, primer annealing at $49^{\circ} \mathrm{C}$ for $1 \mathrm{~min}$ and de novo DNA extension at $72^{\circ} \mathrm{C}$ for $1 \mathrm{~min}$, final elongation step of $72^{\circ} \mathrm{C}$ for $7 \mathrm{~min}$.

sodA gene: the degenerate primers $\mathrm{d} 1$ and d2 were used to amplify an internal fragment, representing approximately $83 \%$ of the sodA gene of streptococci species. The above program was slightly modified (annealing at $37^{\circ} \mathrm{C}-1 \mathrm{~min}$ ) (15).

rроB gene: for staphylococci strains primers $2491 \mathrm{~F}$ and $3554 \mathrm{R}$ were used to amplify a 1.081-bp variable fragment in $r p o B$ gene $\left(52^{\circ} \mathrm{C}\right.$ annealing $\left.-45 \mathrm{~s}\right)(14)$. For streptococci: primer pair $2333 \mathrm{~F}$ and $3073 \mathrm{R}$ amplified a 700 bp product $\left(50^{\circ} \mathrm{C}\right.$ annealing - $\left.30 \mathrm{~s}\right)(11)$.

spa gene: for amplification of the Staphylococcus aureus protein A variable repeat region, primers spa-1113f and spa-1514r were used for amplification. Thermal cycling reactions: 1 cycle $-80^{\circ} \mathrm{C}(5 \mathrm{~min}) ; 35$ cycles $-94^{\circ} \mathrm{C}$ $(45 \mathrm{~s}), 60^{\circ} \mathrm{C}(45 \mathrm{~s}), 72^{\circ} \mathrm{C}(1,5 \mathrm{~min}) ; 1$ cycle $72^{\circ} \mathrm{C}$ (10 min) (24).

PCR amplifications were performed in a volume of $50 \mu \mathrm{l}$ in GeneAmp PCR system 2700 termocycler (Applied Biosystems CA, USA) using High Fidelity PCR Master kit (Roche Diagnostics GmbH, Mannheim, Germany). PCR products were checked by electrophoresis in agarose gel and visualized by ethidium bromide staining. Wizard SV Gel and PCR cleanup system (Promega Corporation, Madison, WI, USA) was used for amplicons purification.

DNA sequencing of purified PCR products. - 16S rRNA gene: five sequencing primers (3 forward: Ad, E, D, and 2 reverse: $\mathrm{rJ}, \mathrm{rE}$ ) were used.
- $\operatorname{sodA}$ gene: both strands of the amplified product were sequenced using the primers $\mathrm{d} 1$ and $\mathrm{d} 2$.

- rроB gene: for staphylococci isolates only $598 \mathrm{bp}$ from amplified $1.081 \mathrm{bp}$ fragment were sequenced using $2643 \mathrm{~F}$ and $3241 \mathrm{R}$ primers. For streptococci isolates, the amplification primers were used also for DNA sequencing.

- spa gene: DNA sequences were obtained using spa-1113f and spa-1514r primers.

Primers used for amplifications and sequencing are listed in Table 1.

Sequencing reactions were performed using ABI Prism BigDye Terminator V3.1 Ready Reaction Cycle Sequencing Kit (Applied Biosystems CA, USA) as described by the manufacturer, in $20 \mu \mathrm{l}$ reaction volume. All the sequencing reaction products were run on $\mathrm{ABI}$ 3100 Avant Genetic Analyzer (Applied Biosystems CA, USA).

All molecular procedures were carried out in separate rooms to avoid contamination events.

The resulting sequences were edited and assembled using BioEdit Sequence Alignment Editor v7.0.9.

For 16S DNA sequencing, the contiguous sequences obtained were compared with those available from NCBI GenBank (http://blast.ncbi. nlm.nih.gov/), Ribosomal Database Project II (http://rdp.cme.msu.edu/) and BLAST Server for the Identification of Prokaryotes (http://bioinfo. unice.fr/blast/).

spa-type sequences were analyzed by Ridom StaphType software (Ridom GmbH, Germany) and synchronized with Ridom spa server (http://spaserver.ridom.de/) $(24,25)$.

Phylogenetic analysis of $r p o B$ and sodA loci was used to assign species designation for streptococcal strains. Neighbor-joining trees were constructed using MEGA version 4 software package (26) and DNA sequence databases from http://viridans.eMLSA.net or from www.immi.au.dk/service/download/kilian.

All molecular procedures were performed at the "Cantacuzino" NIRDMI and each partner from the consortium was informed about the results. 
Table 1: Primers used for amplification and sequencing

\begin{tabular}{|c|c|c|c|c|}
\hline Target gene & Primer & $\begin{array}{c}\text { Gene position } \\
\text { (GenBank acces- } \\
\text { sion no.) } \\
\end{array}$ & 5'-3'direction & References \\
\hline \multirow{5}{*}{ 16S rRNA } & $\begin{array}{l}\text { Ad (PCR and } \\
\text { sequencing) }\end{array}$ & $\begin{array}{c}8-28 \\
(\mathrm{X} 80724) \\
\end{array}$ & AGAGTTTGATCMTGGCTCAG & \multirow{5}{*}{$\begin{array}{l}\text { Weisburg } \\
\text { et al., } 1991\end{array}$} \\
\hline & $\mathrm{rJ}$ (PCR and sequencing) & $\begin{array}{c}1510-1492 \\
(\mathrm{X} 80724)\end{array}$ & GGTTACCTTGTTACGACTT & \\
\hline & $\mathrm{D}$ (sequencing) & $\begin{array}{l}519-536 \\
(\mathrm{X} 80724)\end{array}$ & CAGCAGCCGCGGTAATAC & \\
\hline & $\mathrm{E}$ (sequencing) & $\begin{array}{l}787-806 \\
(\mathrm{X} 80724) \\
\end{array}$ & ATTAGATACCCTGGTAGTCC & \\
\hline & $\mathrm{rE}$ (sequencing) & $\begin{array}{l}787-806 \\
(\mathrm{X} 80724)\end{array}$ & GGACTACCAGGGTATCTAAT & \\
\hline \multirow{2}{*}{$\begin{array}{l}\operatorname{sod} A \\
\text { (streptococci) }\end{array}$} & d1 (PCR and sequencing) & $\begin{array}{c}25-51 \\
(\mathrm{Z} 95896.1) \\
\end{array}$ & CCITAYICITAYGAYGCIYTIGARCC & \multirow{2}{*}{$\begin{array}{l}\text { Poyart et } \\
\text { al., } 1998\end{array}$} \\
\hline & $\mathrm{d} 2$ (PCR and sequencing) & $\begin{array}{c}487-510 \\
(\mathrm{Z} 95896.1)\end{array}$ & ARRTARTAIGCRTGYTCCCAIACRTC & \\
\hline \multirow{4}{*}{$\begin{array}{l}\text { rpoB } \\
\text { (staphylococci) }\end{array}$} & $2491 \mathrm{~F}(\mathrm{PCR})$ & $\begin{array}{c}2491-2511 \\
(X 64172)\end{array}$ & AACCAATTCCGTATIGGTTT & \multirow{4}{*}{$\begin{array}{l}\text { Drancourt } \\
\& \text { Raoult, } \\
2002\end{array}$} \\
\hline & 3554R (PCR) & $\begin{array}{c}3554-3573 \\
(\mathrm{X} 64172)\end{array}$ & CCGTCCCAAGTCATGAAAC & \\
\hline & 2643F (sequencing) & $\begin{array}{c}2643-2660 \\
(\mathrm{X} 64172)\end{array}$ & CAATTCATGGACCAAGC & \\
\hline & 3241R (sequencing) & $\begin{array}{c}3221-3241 \\
(\mathrm{X} 64172)\end{array}$ & GCIACITGITCCATACCTGT & \\
\hline \multirow{2}{*}{$\begin{array}{l}\text { rpoB (strepto- } \\
\text { cocci) }\end{array}$} & $\begin{array}{l}\text { 2333F (PCR and } \\
\text { sequencing) }\end{array}$ & $\begin{array}{l}2333-2363 \\
(\mathrm{AF} 535182) \\
\end{array}$ & AARYTIGGMCCTGAAGAAAT & \multirow{2}{*}{$\begin{array}{l}\text { Drancourt } \\
\text { et al., } 2004\end{array}$} \\
\hline & $\begin{array}{l}\text { 3073R (PCR and } \\
\text { sequencing) }\end{array}$ & $\begin{array}{l}3050-3073 \\
(\mathrm{AF} 535182)\end{array}$ & TGIARTTTRTCATCAACCATGTG & \\
\hline \multirow{2}{*}{$\begin{array}{l}\text { spa } \\
\text { (staphylococci) }\end{array}$} & $\begin{array}{l}\text { spa }-1113 f(P C R \text { and } \\
\text { sequencing) }\end{array}$ & $\begin{array}{l}1092-1113 \\
(\mathrm{~J} 01786)\end{array}$ & TAAAGACGATCCTTCGGTGAGC & \multirow{2}{*}{$\begin{array}{l}\text { Harmsen } e t \\
\text { al., } 2003\end{array}$} \\
\hline & $\begin{array}{l}\text { spa }-1514 \mathrm{r}(\mathrm{PCR} \text { and } \\
\text { sequencing) }\end{array}$ & $\begin{array}{c}1534-1514 \\
(\mathrm{~J} 01786)\end{array}$ & CAGCAGTAGTGCCGTTTGCTT & \\
\hline
\end{tabular}

\section{Results}

\section{Patients}

One hundred and two patients were enrolled in this study. Fifteen patients were excluded because they did not meet the diagnostic requirements for definite IE or received other final diagnosis. Only the remaining 87 cases of definite IE were considered for further studies and discussions.
Among the definite cases, 58 were male; mean age of the patients was 55.2 years (range 21 - 79). Fever occurred in 86 cases. Thirty-six patients received antibiotic treatment in the last week before blood samples were taken, 33 patients did not received antibiotics and for 18 patients status was unknown. Transthoracic and/or trans-esophageal echocardiography was/were performed on all patients and showed vegetations in $77(88.5 \%)$ patients. Ve- 
Table 2. Strain identification by conventional methods and gene sequencing

\begin{tabular}{|c|c|c|c|c|}
\hline \multirow{2}{*}{$\begin{array}{l}\text { Final identification } \\
\text { (no. of isolates) }\end{array}$} & \multicolumn{4}{|c|}{ Identification according to following test methods: } \\
\hline & Conventional $^{*}$ & $16 S r R N A$ & $r p o B$ & $\operatorname{sod} A$ \\
\hline \multicolumn{5}{|c|}{ Gram positive bacteria $(n=33)$} \\
\hline S. aureus (4) & S. aureus & S. aureus & S. aureus & $-{ }^{* * *}$ \\
\hline $\begin{array}{l}\text { Staphylococcus epi- } \\
\text { dermidis (5) }\end{array}$ & S. epidermidis & S. epidermidis & S. epidermidis & - \\
\hline $\begin{array}{l}\text { Staphylococcus hom- } \\
\text { inis (2) }\end{array}$ & S. hominis & S. hominis & S. hominis & - \\
\hline $\begin{array}{l}\text { Staphylococcus hae- } \\
\text { molyticus (1) }\end{array}$ & $\mathrm{CNS}^{* * *}$ & S. haemolyticus & S. haemolyticus & - \\
\hline Kocuria kristinae (1) & $\begin{array}{l}\begin{array}{l}\text { Staphylococcus hom- } \\
\text { inis }\end{array} \\
\end{array}$ & K. kristinae & - & - \\
\hline Streptococcus mitis (1) & S. mitis/oralis & S. mitis /oralis & S. mitis & S. mitis \\
\hline $\begin{array}{l}\text { Streptococcus para- } \\
\text { sanguinis (1) } \\
\end{array}$ & \begin{tabular}{|l|}
$\begin{array}{l}\text { Streptococcus } \\
\text { anginosus }\end{array}$ \\
\end{tabular} & S. parasanguinis & - & S. parasanguinis \\
\hline $\begin{array}{l}\text { S. gallolyticus ssp. gal- } \\
\text { lolyticus (5) }\end{array}$ & $\begin{array}{l}\text { S. gallolyticus ssp. gal- } \\
\text { lolyticus }\end{array}$ & $\begin{array}{l}\text { S. gallolyticus ssp. gal- } \\
\text { lolyticus }\end{array}$ & \begin{tabular}{|l|}
$\begin{array}{l}\text { S. gallolyticus ssp. } \\
\text { gallolyticus }\end{array}$ \\
\end{tabular} & \begin{tabular}{|l}
$\begin{array}{l}\text { S. gallolyticus ssp. } \\
\text { gallolyticus }\end{array}$ \\
\end{tabular} \\
\hline $\begin{array}{l}\text { S. gallolyticus ssp. } \\
\text { pasteurianus (1) }\end{array}$ & $\begin{array}{l}\text { Streptococcus pasteuri- } \\
\text { anus }\end{array}$ & $\begin{array}{l}\text { S. gallolyticus ssp. pas- } \\
\text { teurianus }\end{array}$ & $\begin{array}{l}\text { S. gallolyticus ssp. } \\
\text { pasteurianus }\end{array}$ & $\begin{array}{l}\text { S. gallolyticus ssp. } \\
\text { pasteurianus }\end{array}$ \\
\hline Streptococcus. equi (1) & $\begin{array}{l}\text { Streptococcus dis- } \\
\text { galactiae } \text { ssp. } \\
\text { equisimilis }\end{array}$ & Streptococcus equi & S. equi & S. equi \\
\hline Streptococcus sp. (1) & S. sanguinis & Streptococcus sp. & Streptococcus sp. & Streptococcus sp. \\
\hline $\begin{array}{l}\text { Granulicatella adi- } \\
\text { acens }(1)\end{array}$ & G. adiacens & G. adiacens & - & - \\
\hline E. faecalis (7) & E. faecalis & E.faecalis & E.faecalis & E. faecalis \\
\hline $\begin{array}{l}\text { Enterococcus gallinar- } \\
\text { um (1) }\end{array}$ & $\begin{array}{l}\text { Enterococcus casseli- } \\
\text { flavus }\end{array}$ & $\begin{array}{l}\text { E. gallinarum/ E. casseli- } \\
\text { flavus }\end{array}$ & E. gallinarum & E. gallinarum \\
\hline $\begin{array}{l}\text { Brevibacterium casei } \\
\text { (1) }\end{array}$ & Corynebacterium sp. & B. casei & - & - \\
\hline \multicolumn{5}{|c|}{ Gram negative bacteria $(n=4)$} \\
\hline E. $\operatorname{coli}(1)$ & E. coli & E. coli & - & - \\
\hline E. cloacae $(1)$ & E. cloacae & E. cloacae & - & - \\
\hline Acinetobacter sp. (1) & Alcaligenes faecalis & Acinetobacter sp. & - & - \\
\hline $\begin{array}{l}\text { Pseudomonas fluores- } \\
\text { cens (1) }\end{array}$ & P. aeruginosa & P. fluorescens & - & - \\
\hline
\end{tabular}

*Boldface type indicates misidentification or ambiguous (incomplete) identification by conventional methods.

** not done

*** coagulase-negative staphylococci

getations were present on the mitral valve (26 native, 12 prosthetic) in $38(43.7 \%)$ patients, on the aortic valve (20 native, 4 prosthetic) in 24 $(27.6 \%)$ patients, on the tricuspid native valve in two cases $(2.3 \%)$ and in 13 cases (14.9\%) more than one valve or a valve and another car- diac structure were involved. Surgical treatment of IE was performed in 27 cases (31\%). In-hospital mortality occurred in 9 cases $(10.3 \%)$.

\section{Laboratory procedures}

Fifty-five out of 87 patients with definite IE had positive blood cultures. In thirteen 
cases out of 55, patients received antibiotic treatment before the blood-cultures were taken, for 17 patients this data were not available. When the blood cultures were negative, in 23 out of 32 cases, patients received antibiotic therapy prior blood samples collection.

Twelve tissue fragments with vegetations on the native valves ( 6 mitral, 3 aortic, 1 tricuspid) or on the mechanical prosthesis (1 mitral and 1 aortic) recovered from 10 patients were available for culturing and molecular testing. In two cases both mitral (natives) and aortic valves (1 native and 1 prosthetic) were available. Eleven valves were recovered from patients with $\mathrm{BCNE}$ and one from a patient with positive blood cultures. For two BCNE cases, both mitral (natives) and aortic valves (1 native and 1 prosthetic) were available. Culturing of available valve tissues did not lead to recovery of etiological agents.

\section{Blood culture positive cases}

Bacteria recovered from blood cultures and identified by phenotypic methods were: staphylococci (20 strains), streptococci (16 strains), enterococci (9 strains), other Grampositive bacteria (3 strains), Gram-negative bacteria (3 strains) and in three cases co-infection occurred. Regarding these last three cases, bacteremia occurred at short time (less than 2 months) after cardiac interventions: two patients received pacemakers and one patient a biological prosthesis, and were considered health-care associated infections.

Only 37 out of 57 strains recovered from definite IE blood cultures were available for molecular identification.

Results obtained by phenotypic methods were in accordance with molecular identification results for 28 bacterial strains (Table 2). Similarity with sequences from databases was equal or more than $99 \%$.

Conventional species identification disagreed with gene sequencing results for 8 isolates. All those isolates were phenotypical identified by Vitek 2, except Corynebacterium sp/ Brevibacterium casei, when specific ANC Vitek 2 card was missing. Molecular identification completed the initial diagnostic for one staphylococcal strain, identified by Vitek 2 only as coagulase-negative staphylococcus (Table 2). For three strains another genus was assigned by gene sequencing methods (Staphylococcus/ Kokuria; Corynebacterium/ Brevibacterium; Alcaligenes/ Acinetobacter). The five isolates phenotypically identified as Streptococcus gallolyticus ssp. gallolyticus and one isolate identified as S. gallolyticus ssp. pasteurianus demonstrated concordance with all three gene targets in molecular identification. All but one streptococcal strain were assigned with species names on the basis of positions on phylogenetic rpoB and sodA trees. One isolate, phenotypically identified as Streptococcus sanguinis, did not fall within known species clusters and had a $<99 \% 16 \mathrm{~S}$ rRNA sequence similarity with more type strains from mitis group streptococci (Streptococcus pseudopneumoniae/ Streptococcus mitis/ Streptococcus pneumoniael Streptococcus oralis). A phylogenetic sequence analysis of more housekeeping genes or others methods are necessary in order to assign a species name for this isolate.

In one case, an appropriate piece of valve was available and was analyzed by PCR for bacterial detection. The same $S$. aureus strain recovered from blood was detected in heart valve. Isolates identity was verified by spa typing, both isolates sharing the same spa type - t284. Additionally, for other three available $S$. aureus strains a spa type was assigned: t005, t5891, t5890.

\section{Blood culture negative cases}

When conventional techniques did not led to etiological agent identification, the laboratory diagnosis was based on valve tissue analysis for bacterial DNA detection.

Following the DNA extraction from the eleven valvular fragments, four positive PCR amplifications for $16 \mathrm{~S}$ rRNA bacterial gene were obtained. Using $16 \mathrm{~S}$ rRNA sequencing, $S$. gallolyticus ssp. gallolyticus was identified in both mitral and aortic native valves from one patient. For another two BCNE cases, etiologic- 
al agents identified from resected valves were S. gallolyticus ssp. gallolyticus and, S. aureus, respectively. These results, obtained by $16 \mathrm{~S}$ rRNA sequencing using universal primers, were also confirmed by rpoB and $\operatorname{sod} A$ sequencing for streptococci and $r p o B$ for staphylococci.

\section{Discussion}

This study aimed at implementing molecular methods for identification of any bacterial species encountered in IE, and to attempt reducing the number of cases with unknown etiology. Therefore, in this study were involved specialists from clinical and laboratory domains, in order to cover all the scientific and logistic requirements.

Positive blood cultures remain the cornerstone of diagnosis and provide live bacteria for susceptibility testing. Phenotypic identification tests for bacteria are inherently subjected to problems: variability of phenotypic expression within a given species, the corresponding databases are not up-to-date, results rely on individual expertise and interpretation and sometimes, alterations in the execution of an assay may give false test results. Due to these limitations, molecular identification could be a helpful alternative in some cases (4, 6-10). However, molecular biology techniques are not fully available to clinical laboratories and are more laborious and expensive than the conventional identification techniques. Also, contamination of samples with foreign DNA can be problematic when the different steps can't be performed in different areas.

In this study, available isolates were identified by phenotypic and molecular comparative methods (16S rRNA, sodA and/or rpoB genes sequencing).

Molecular identifications were performed to (sub)species level. There are studies that clearly show that species or even subspecies identification may have substantial impact on the management of patients (4). This is the case of S. gallolyticus ssp. gallolyticus versus other subspecies. The first one is often accompanied by colonic tumours, while ssp. pasteurianus and ssp. macedonicus are less frequently associated with colonic disorders (27-29).

In some studies, up to $25 \%$ of the initial microbiological diagnoses were corrected using the mentioned molecular techniques $(30,31)$.

The requirement for a unique identification method was not established in the study design and can be considered as a weakness of the study; nevertheless, discrepancies between the identification results obtained by molecular and phenotypic techniques were observed. Comparative identification provided here demonstrated that molecular identification was more accurate than classical phenotypic identification in nine cases (eight misidentifications, one incomplete identification) and, when possible or needed, this approach could provide the alternative of an appropriate identification, which can be useful in patients therapy management.

A big concern at the beginning of the study was the high number of BCNE, often delaying etiological diagnosis and the initiation of treatment, with profound impact on clinical outcome. Antibiotic therapy for these cases is based on empirical treatment. The initial choice of empirical treatment depends on several considerations including knowledge of local epidemiology and specific culture-negative pathogens (32).

In the ENDOBACT study, the diagnostic strategy for BCNE included serological testing of fastidious agents, but the methods and results for C. burnetii, Bartonella quintana and Bartonella henselae detection are presented in the article of Cotar et al., 2011 (33).

Supplementary, sera from patients with known etiology were tested in order to detect possible co-infections (Cotar, unpublished data). The corresponding sera for patients with positive blood cultures exhibited also IgG phase I antibody for $C$. burnetii in four cases, with titers compatible with endocarditis (Cotar, unpublished data). Co-infections with $C$. burnetii occurred for patients with positive blood cultures for S. aureus/Stenotrophomonas malto- 
Table 3. Causative bacteria in IE - ENDOBACT study (no. of isolates)

\begin{tabular}{|l|l|l|l|l|l|}
\hline $\begin{array}{l}\text { Staphylococci } \\
(\mathbf{1 8})\end{array}$ & Streptococci (20) & Enterococci (8) & $\begin{array}{l}\text { Other Gram } \\
\text { positive bacteria } \\
\mathbf{( 3 )}\end{array}$ & $\begin{array}{l}\text { Gram negative } \\
\text { bacteria (10) }\end{array}$ & Co-infections (7) \\
\hline S. aureus (8) & $\begin{array}{l}\text { S. gallolyticus ssp. } \\
\text { gallolyticus (9) }\end{array}$ & E. faecalis (7) & G. adiacens (2) & C. burnetii (8) & $\begin{array}{l}\text { C. burnetii }+ \text { S. } \\
\text { gallolyticus ssp. } \\
\text { gallolyticus }(1)\end{array}$ \\
\hline $\begin{array}{l}\text { S. epidermidis } \\
(5)\end{array}$ & $\begin{array}{l}\text { S. gallolyticus ssp. } \\
\text { pasteurianus (1) }\end{array}$ & $\begin{array}{l}\text { E. gallinarum } \\
(1)\end{array}$ & G. sanguinis (1) & $\begin{array}{l}\text { P. fluorescens } \\
(1)\end{array}$ & C. burnetii + S. aureus (1) \\
\hline S. hominis (2) & $\begin{array}{l}\text { viridans } \\
\text { streptococci (6) }\end{array}$ & & & E. coli (1) & $\begin{array}{l}\text { C. burnetii }+ \text { S. } \\
\text { maltophilia }(1)\end{array}$ \\
\hline other CNS (3) & $\begin{array}{l}\text { other streptococci } \\
(4)\end{array}$ & & & $\begin{array}{l}\text { C. burnetii }+ \text { S. } \\
\text { constellatus ssp. faryngis } \\
(1)\end{array}$ \\
\hline & & & & $\begin{array}{l}\text { E. cloacae }+ \\
\text { Acinetobacter } \text { sp.(1) }\end{array}$ \\
\hline & & & $\begin{array}{l}\text { S. haemolyticus }+ \text { B. casei } \\
(1)\end{array}$ \\
\hline
\end{tabular}

philial Streptococcus constellatus ssp. faryngis or S. gallolyticus ssp. gallolyticus.

These findings suggest that systematic serological testing for this fastidious bacterium in each case of possible or definite IE could be useful. In common practice, clinicians consider serological testing only when the blood cultures are negative. Raoult et al. (34) strongly recommend performing both blood cultures and serological tests at the same time. This approach could shorten the time until initiation of appropriate therapy, the length of hospitalization and, in some cases, could detect poly-microbial endocarditis. A recent study performed in the Netherlands, also revealed the usefulness of systematic serological testing for detecting poly-microbial endocarditis. This approach is recommended especially in areas where $\mathrm{Q}$ fever is endemic (35).

Another strategy applied in order to minimize the number of BCNE was molecular analysis of valves with vegetations excised from patients who underwent surgical interventions. Thirty- eight patients had indication for cardiac surgery, but only 27 suffered the intervention.

Only 12 pieces from 10 patients were available for molecular study. Using universal primers for eubacteria a confirmatory identification of $S$. aureus IE was obtained in one case with positive blood cultures. Also, the causative agents in 3 cases with previously unknown etiology were identified: two $S$. gallolyticus ssp. gallolyticus and one $S$. aureus. These pathogens are usually easily culturable, but in our cases, all 3 patients received antibiotics prior blood culturing.

The high sensitivity of 16S rRNA PCR technique allows the detection of few or non-viable bacteria in valve tissue. But this issue can be a source of false-positive results, when a small amount of bacterial DNA contaminated culture media, reagents or sample during collection and processing.

As other authors suggested $(5,7,10)$, 16S rRNA gene sequencing directly from valve tissue extracted DNA may improve microbiological diagnosis in surgically treated patients with IE, but the results should always be interpreted with cautions.

The causative bacteria of IE detected in ENDOBACT study by phenotypic, serologic and/or molecular testing were listed in Table 3. 
Several studies indicate that $S$. aureus rate in IE is increasing, especially because of nosocomial acquisitions and drug consumption (38-40). In ENDOBACT study, the $S$. aureus strains were fewer than coagulase negative staphylococci and streptococci. Vegetations (usually with large size) occurred for each patient, in eight cases on native valve, in one case on prosthetic valve. For three strains nosocomial acquisition may be suspected, following gastrointestinal, ophthalmological or dental interventions. No drug consumers were detected in our study group. All available $S$. aureus strains were detected methicillin-sensitive, by PCR targeting mecA gene, unlike coagulase-negative staphylococci (CNS) which were all methicillin-resistant (Oprea, unpublished data).

CNS and viridians streptococci endocarditis occurred mostly on the prosthetic devices (70\% for staphylococci and 100\% for streptococci). Half of the Enterococcus faecalis endocarditis involved prosthesis and nosocomial acquisition is suspected in one case when bacteremia with E. faecalis appeared at short time after patient received a mechanical valve.

Of note it is the increased number of $S$. gallolyticus ssp. gallolyticus isolates. It is estimated that between 18 and $62 \%$ of the patients with S. gallolyticus ssp. gallolyticus endocarditis have underlying colorectal tumors, sometimes with no signs or symptoms referable to gastrointestinal disease. Many studies have been conducted to elucidate this relation (29, 41-43). In a recent study, authors consider that $S$. gallolyticus ssp. gallolyticus, based on his pro-inflammatory potential and pro-carcinogenetic properties is most probably responsible for slow progressing carcinogenesis of colorectal mucosal tissues (27). Also, this bacterium is associated with liver diseases or dysfunction $(44,45)$.

Two from our S. gallolyticus ssp. gallolyticus patients had already known colonic neoplasia, and one had chronic liver disorders. The physicians in charge to monitor the others were advised to perform a more rigorous control. The early detection of colorectal adenomas or carcinomas via detection of S. gallolyticus ssp. gallolyticus might be of high value in screening high risk groups for colorectal cancer.

Aerobic Gram negative bacilli are rare causes of IE. We report 3 community acquisitions of Pseudomonas fluorescens, S. maltophilia and Escherichia coli. The poly-microbial Gram negative endocarditis Enterobacter cloacae + Acinetobacter sp. is probably of nosocomial origin, after a recent pacemaker implantation.

The remaining cases without defined etiology can be attributed to fungal, viral infections, other fastidious bacteria non - tested here and maybe non-infective endocarditis (8). In some cases, administration of antimicrobial agents to IE patients before blood cultures had reduced the chances of bacteria recovery.

It is worth noting that not all of the excised valves in BCNE cases were received for molecular testing. As is a proven fact that is possible to identify the causative bacteria from cardiac tissue with vegetations by PCR targeting 16S rRNA gene, surgeons must better collaborate with laboratory staff in order to improve the findings related to valve pieces.

Overall, the Romanian panel of causative agents of IE is similar with that reported by studies from other countries (36-38), with a high prevalence of staphylococci and streptococci, as presented in Table 3.

\section{Conclusion}

When phenotypical identification was complemented by molecular and serological testing in IE diagnosis, the percentage of IE cases with unknown etiology decreased from $36.8 \%$ to $24.1 \%$. Additionally, in four cases the diagnosis was modified from single causative agent infection to co-infection, after identification of significant levels of $\operatorname{IgG}$ phase I to $C$. burnetii along with the bacterial species recovered from blood culture. For nine strains molecular identification changed or completed the initial phenotypic identification.

A better understanding of the spectrum of bacteria causing IE in our country can guide 
to the most appropriate empirical treatment in BCNE. Also, a rapid and correct diagnostic will improve the medical act in benefits of patients, resulting in appropriate treatment and shorter stay in the hospital.

We conclude that this study gave a better perspective to investigation and management of IE in Romania.

\section{Acknowledgements}

This study was supported by the Romanian Ministry of Education, Research, Youth and Sports, CNMP-UEFISCDI Project PARTENERIATE 42-119/2008, grant awarded to Monica Straut. We kindly thank all the partners in ENDOBACT project and Mrs. SilviaMariana Cretoiu which actively participated during the first half of this project.

\section{References}

1. Beynon RP, Bahl VK, Prendergast BD. Infective endocarditis. Brit Med J. 2006; 333:334-9.

2. Moreillon P, Que YA. Infective endocarditis. Lancet. 2004; 363: 139-49.

3. Mylonakis E, Calderwood SB. Infective Endocarditis in adults. N Engl J Med. 2001; 345: 1318-30.

4. Podglajen I, Bellery F, Poyart C, Coudol P. Comparative molecular and microbiologic diagnosis of bacterial endocarditis. Emerg Infect Dis. 2003; 9(12):1543-47.

5. Miyazato A, Ohkusu K, Tabata M, Uwabe K, Kawamura T, Tachi Y, Ezaki T, Niinami H, Mitsutake K. Comparative molecular and microbiological diagnosis of 19 infective endocarditis cases in which causative microbes were identified by PCR-based DNA sequencing from the excised heart valves. J Infect Chemoter. 2011; 18(3):318-23.

6. Benslimani A, Fenollar F, Lepidi H, Raoult D. Bacterial zoonoses and infective endocarditis, Algeria. Emerg Infect Dis 2005; 11(2):216-224.

7. Breitkopf C, Hammel D, Scheld HH, Peters G, Becker $\mathrm{K}$. Impact of a molecular approach to improve the microbiological diagnosis of infective heart valve endocarditis. Circulation. 2005; 111:1415-21.

8. Fournier PE, Thuny F, Richet H. Comprehensive diagnostic strategy for blood culture-negative endocarditis: a prospective study of 819 new cases. Clin Infect Dis. 2010; 51:131-40.

9. Tak T, Shukla SK. Molecular Diagnosis of infective endocarditis: a helpful addition to the Duke criteria. Clin
Med Res. 2004; 2(4): 206-8.

10. Vondracek M, Sartipy U, Aufwerber E, Julander I, Lindblom D, Westling K. 16S rDNA sequencing of valve tissue improves microbiological diagnosis in surgically treated patients with infective endocarditis. J Infection. 2011;62:472-8.

11. Drancourt M, Roux V, Fournier PE, Raoult D. rpoB gene sequence-based identification of aerobic Gram-positive cocci of the genera Streptococcus, Enterococcus, Gemella, Abiotrophia, and Granulicatella. J Clin Microbiol. 2004; 42(2):497-504.

12. Glazunova OO, Raoult D, Roux V. Partial sequence comparison of the rpoB, sodA, groEL and gyrB genes within the genus Streptococcus. Int J Syst Evol Microbiol. 2009; 59(9):2317-22.

13. Stackebrandt E, Goebel BM. A place for DNA-DNA reassociation and 16S rRNA sequence analysis in the present species definition in bacteriology. Int J Syst Bacteriol. 1994; 44: 846-9.

14. Drancourt M, Raoult D. rpoB gene sequence-based identification of Staphylococcus species. J Clin Microbiol. 2002; 40(4):1333-8.

15. Poyart C, Quesne G, Coulon S, Berche P, Trieu-Cuot P. Identification of streptococci to species level by sequencing the gene encoding the manganese-dependent superoxide dismutase. J Clin Microbiol. 1998; 36:41-47.

16. Brouqui $P$, Raoult $D$. New insight into the diagnosis of fastidious bacterial endocarditis. FEMS Immunol Med Microbiol. 2006; 47:1-13.

17. Grijalva M, Horvath R, Dendis M, Erny J, Benedik J. Molecular diagnosis of culture negative infective endocarditis: clinical validation in a group of surgically treated patients. Heart. 2003; 89:263-8.

18. Picu C, Mille C, Popescu GA, Bret L, Prazuck T. Aortic prosthetic endocarditis with Neisseria elongata subspp. nitroreducens. Scand J Infect Dis. 2003; 35(4):12-4.

19. Popescu GA, Prazuck T, Poisson D, Picu C. A "true" polymicrobial endocarditis: Candida tropicalis and Staphylococcus aureus to a drug user. Case presentation and literature review. Rom J Intern Med. 2005a; 43:15761.

20. Popescu GA, Benea E, Mitache E, Piper C, Horstkotte D. An unusual bacterium, Aerococcus viridans, and four cases of infective endocarditis. J Heart Valve Dis. 2005b; 14(3):317-9.

21. Tilea I, Tilea B, Suciu H,Tatar CM. Particularities of infective endocarditis. A retrospective study. Rev Romana Med Lab. 2009; 16(3): 41-47.

22. Li JS, Sexton DJ, Mick N, Nettles R, Fowler VG Jr, Ryan T, et al. Proposed modifications to the Duke criteria for the diagnosis of infective endocarditis. Clin Infect Dis. 2000; 30:633-38.

23. Weisburg WG, Barns SM, Pelletier DA, Lane DJ. $16 \mathrm{~S}$ ribosomal DNA amplification for phylogenetic study. J Bacteriol. 1991; 173(2): 697 - 70.

24. Harmsen D, Claus H, Witte W, Rothgänger J, Claus 
H, Turnwald D, Vogel U. Typing of methicillin-resistant Staphylococcus aureus in a university hospital setting using a novel software for spa-repeat determination and database management. J Clin Microbiol. 2003; 41:544248.

25. Hallin, M., Friedrich, A.W. \& Struelens, M. spa typing for epidemiological surveillance of Staphylococcus aureus. Methods Mol Biol. 2009; 551: 189-202.

26. Tamura K, Dudley J, Nei M, Kumar S. MEGA 4: Molecular Evolutionary Genetics Analysis (MEGA) software version 4.0. Mol Biol Evol. 2007; 24:1596-9.

27. Abdulamir AS, Hafidh RR, Bakar FA. The association of Streptococcus bovis/gallolyticus with colorectal tumors: The nature and the underlying mechanisms of its etiological role. J Exp Clin Canc Res. 2011; 30:11.

28. Devriese LA, Vandamme P, Pot B, Vanrobaeys M, Kersters K, Haesebrouck F. Differentiation between Streptococcus gallolyticus strains of human clinical and veterinary origins and Streptococcus bovis strains from the intestinal tracts of ruminants. J Clin Microbiol. 1998; 36:352023.

29. Sillanpää J, Nallapareddy SR, Singh KV, et al. Adherence characteristics of endocarditis - derived Streptococcus gallolyticus ssp. gallolyticus (Streptococcus bovis biotype I) isolates to host extracellular matrix proteins. FEMS Microbiol Lett. 2008; 289(1):104-9.

30. Abdul-Redha RJ, Kemp M, Bangsborg JM, Arpi M, Jørgen Christensen J. Infective endocarditis: Identification of catalase-negative, Gram-positive cocci from blood cultures by partial $16 \mathrm{~S}$ rRNA gene analysis and by Vitek 2 examination. Open Microbiol J. 2010; 4:116-22.

31. Gauduchon V, Chalabreysse L, Etienne J, Celard M, Benito Y, Lepidi H, et al. Molecular diagnosis of infective endocarditis by PCR amplification and direct sequencing of DNA from valve tissue. J Clin Microbiol. 2003; 41(2):763-6.

32. Habib G, Hoen B, Tornos P, Thuny F, Prendergast $\mathrm{B}$, Vilacosta I, et al. Guidelines on the prevention, diagnosis, and treatment of infective endocarditis (new version 2009): the Task Force on the Prevention, Diagnosis, and Treatment of Infective Endocarditis of the European Society of Cardiology (ESC). Endorsed by the European Society of Clinical Microbiology and Infectious Diseases (ESCMID) and the International Society of Chemotherapy (ISC) for Infection and Cancer. Eur Heart J. 2009; 30(19):2369-413.

33. Cotar AI, Badescu D, Oprea M, Dinu S, Banu O, Dobreanu D, Dobreanu M, Flonta M, Straut M. Q Fever endocarditis in Romania: the first cases confirmed by direct sequencing. Int J Mol Sci. 2011; 12(12): $9504-13$.

34. Raoult D, Casalta JP, Richet H, Khan M, Bernit E, Rovery C, et al. Contribution of systematic serological testing in diagnosis of infective endocarditis. J Clin Microbiol. 2005; 43(10):5238-42.

35. Kampschreur LM, Oosterheert JJ, de Vries Feyens CA, Delsing CE, Hermans MH, van Sluisveld IL, et al.
Chronic Q fever-related dual-pathogen endocarditis: case series of three patients. J Clin Microbiol. 2011; 49(4):1692-4.

36. Baddour LM, Wilson WR, Bayer AS, Fowler VG Jr, Bolger AF, Levison ME, et al. Infective Endocarditis diagnosis, antimicrobial therapy and management of complications: a statement for healthcare professionals from the Committee on Rheumatic Fever, Endocarditis and Kawasaki disease, Council on Cardiovascular Disease in the Young, and the Councils on Clinical Cardiology, Stroke, and Cardiovascular Surgery and Anesthesia, American Heart Association: Endorsed by the Infectious Diseases Society of America. Circulation. 2005; 111:e394e434.

37. Loupa C, Mavroidi N, Boutsikakis I, Paniara O, Deligarou O, Manoli H, Saroglou G. Infective endocarditis in Greece: a changing profile. Epidemiological, microbiological and therapeutic data. Clin Microbiol Infect. 2004; 10:556-61.

38. Millar BC, Prendergast BD, Moore JE. Community-associated MRSA (CA-MRSA): an emerging pathogen in infective endocarditis. J Antimicrob Chemoth. 2008; 61:1-7.

39. Fowler VG, Miro JM, Hoen B, Cabell CH, Abrutyn E, Rubinstein E, et al. Staphylococcus aureus endocarditis. A consequence of medical progress. J Amer Med Asoc. 2005; 293(24):3012-21.

40. Hill EE, Peetermans WE, Vanderschueren S, Claus P, Herregods MC, Herijgers P. Methicillin-resistant versus methicillin-sensitive Staphylococcus aureus infective endocarditis. Eur J Clin Microbiol Infect Dis. 2008; 27:44550 .

41. Abdulamir AS, Hafidh R, Abu Bakar F. Molecular detection, quantification, and isolation of Streptococcus gallolyticus bacteria colonizing colorectal tumors: inflammation-driven potential of carcinogenesis via IL-1, COX2, and IL-8. Mol Cancer. 2010; 9:249.

42. Boleij A, Roelofs R, Schaeps RM, Schülin T, Glaser $\mathrm{P}$, Swinkels DW, et al. Increased exposure to bacterial antigen RpL7/L12 in early stage colorectal cancer patients. Cancer. 2010; 116:4014-22.

43. Tjalsma H, Scholler-Guinard M, Lasonder E, Ruers TJ, Willems HL, Swinkels DW. Profiling the humoral immune response in colon cancer patients: diagnostic antigens from Streptococcus bovis. Int J Cancer. 2006; 119: 2127-35.

44. Savu O, Şerban M, Iacob R, Moldovan H, Şerban-Barbu V, Becheanu G, Banu O, Ginghina C. Endocarditis due to Streptococcus gallolyticus and colonic high grade dysplasia - a case report. Romanian Journal of Cardiology. 2011; 21(4): 335-9.

45. Tripodi MF, Adinolfi LE, Ragone E, Mangoni ED, Fortunato R, Iarussi D, et al. Streptococcus bovis endocarditis and its association with chronic liver disease: an underestimated risk factor. Clin Infect Dis. 2004; 38(10):1394-1400. 